Arkadiusz Bagłajewski

Instytut Filologii Polskiej, Uniwersytet Marii Curie-Skłodowskiej

\title{
Romantyzm polityczny Jarosława Jakubowskiego albo przepisywanie Dziadów (na prawicy)
}

Dlaczego Dziady odżywają w polskim teatrze i dramaturgii po roku 2010? Odwołując się do wywodu Jacka Kopcińskiego, można powiedzieć, że arcydramat jest mitotwórczą matrycą zarówno teatru krytycznego, jak i teatru wspólnoty wyobrażonej - stale dostarcza symboli, idiomów, języka, które są odnoszone do politycznej diagnozy współczesności, będącej repetycją ujawnionego przez Adama Mickiewicza wzoru postaw wspólnotowych [zob. Kopciński 2016: 258-262]. Jak można sądzić, szczególnie nośne okazało się w politycznej lekturze dramatu - zwłaszcza w nawiązaniach literackich - sięgnięcie do scen par excellence politycznych: sceny więziennej i zwłaszcza Salonu warszawskiego, z zastąpieniem „tradycyjnego podziału na kolaborantów i spiskowców $[\ldots]$ zupełnie innym antagonizmem: establishment versus wykluczeni” [Kopciński 2016: 261]. Wydawałoby się, że koncept Kopcińskiego formułowany na kanwie interpretacji teatralnej Pawła Wodzińskiego z przedstawienia Mickiewicz. Dziady. Performance ujawnia się również w wierszach smoleńskich: Jarosława Marka Rymkiewicza, Krzysztofa Koehlera, Wojciecha Wencla [zob. Bagłajewski 2015: 195-214], a także w dramaturgii Jarosława Jakubowskiego, będącej przedmiotem mojego omówienia. Jed- 
nak to pozorne podobieństwo: Wodzińskiego w postkolonialnej lekturze Mickiewicza „interesuje jednak inna kwestia: czy nasza romantyczna niewolniczo-wyzwoleńcza mentalność nie fałszuje realnych konfliktów społecznych?” [Kopciński 2016: 240]. Z kolei kojarzonych z prawicą pisarzy zajmuje - powiedzmy to od razu instrumentalne wykorzystanie romantycznej dychotomii; jeśli nawet przedstawiają wykluczonych i poniżonych, to nakładają na to rozpoznanie ową romantyczną kliszę „krzyża na piersiach”, przeciwstawianego „zdrajcom narodowej sprawy w dobrze skrojonych garniturach" [Kopciński 2016: 240]. Przywołałem więc poręczne rozpoznanie Kopcińskiego, by wskazać już na wstępie rozważań zawłaszczenie dyskursywne polegające na „przejęciu” przez prawicę języka lewicowego, nakładanego na patriotyczne, mesjanizujące rozpoznanie romantyczne. Ów wędrujący kontekst przejmowanych formuł będzie miał, jak się okaże w toku wywodu, kluczowe znaczenie w mechanizmie przepisywania kodu romantycznego, dokonywanego przez pisarza podkreślającego swe prawicowe poglądy.

W autorskim posłowiu do zbioru dramatów Jakubowskiego, autora głośnego Generała, czytamy o utworze napisanym w 2013 roku, zatytułowanym Nowy Legion czyli Świt albo Samowyzwolenie. Historia o sześciu śmierciach i jednym zmartwychwstaniu Adama Mickiewicza wierszem, następujące słowa:

I wreszcie najnowszy z zamieszczonych tu dramatów - Nowy Legion - i kolejne pytanie: czy paradygmat romantyczny w naszej kulturze jest nadal aktualny i żywotny? Dla mnie to oczywiste. Co więcej, stanowi najpożywniejszy pokarm polskiej kultury. Adam Mickiewicz wstaje z martwych, żeby ponownie zorganizować Legion Polski, legion ludzi „biorących się za bary” z życiem takim, jakim ono jest. A przez to odzyskujących podmiotowość. [Jakubowski 2014: 378] ${ }^{1}$

Dwa ostatnie zdania, będące krótką rekapitulacją utworu, należałoby dopełnić o ważne zdania kolejne. Mickiewicz wstaje tu 
z martwych, ale - zgodnie z podtytułem - sześć razy umiera. Sześć śmierci Mickiewicza, wydzielonych w strukturze dramatu, stanowi podstawowy czynnik kompozycyjny utworu, złożonego z czegoś na kształt sześciu scen dramatycznych, otoczonych prologiem i epilogiem. Warto na wstępie rozważań podkreślić, że interpretowany utwór został wydrukowany w tomie zatytułowanym Generał i inne dramaty polityczne. Ważne jest tu rozumienie „polityczności” dramatu, dość zdawkowo objaśniane przez autora w posłowiu. Kreśli on w tej kwestii następujące słowa:

Podtytuł „dramaty polityczne” jest znakiem, że nie zamierzam uchylać się od udziału w życiu zbiorowości. Mam nadzieję, że mój głos i głosy, które przywołuję w utworach scenicznych, przyczynią się w pewnym stopniu do tego, że pojęcie „dramat polityczny” zostanie uwolnione od piętna kawiarnianej agitki. [Jakubowski 2014: 378 $]^{2}$

Tyle autor. Żałować można, że nie dodał ważnej informacji o polityczności swoich propozycji, mianowicie, iż jest to polityczność prawicowa, formułowana w toku polemiki z „lewicowo-liberalnym” obrazem świata ${ }^{3}$. Do kwestii tej przyjdzie wrócić w toku prowadzonego wywodu. W tym momencie chciałbym wskazać dość oczywisty, lecz niewyeksponowany w autorskim słowie, kontekst polityczności dramatu Jakubowskiego, jakim

2 Swoją drogą, dziwić może owa „kawiarniana agitka” w wypowiedzi pisarza prawicowego, jako żywo przypominająca relikt komunistycznej nowomowy.

Zwięzłą charakterystykę współczesnych dyskursów politycznych zawiera praca Jerzego Bartmińskiego [2010: 17-21]. Tu charakterystyka dyskursu narodowo-prawicowego (zorganizowanego wokół pojęć: narodu, silnego, scentralizowanego państwa, solidarności społecznej, odrzucenia absolutnej równości, eksponowania prorodzinności, antyeuropejskości oraz odwołania do tradycyjnej, „ludowej” religijności) oraz „pisomowy”, opartej na idei walki politycznej z wykreowaniem wroga w ramach dychotomii my - wy [zob. Bartmiński 2010: 19]. Charakterystyki dyskursów prawicowych, odnoszonych do lat 90. Xx wieku i ujawniających się $\mathrm{w}$ debatach nie tylko politycznych lat 2005-2007, pojawiają się także w innych artykułach drukowanych w książce Język IV Rzeczypospolitej [zob. np. Czyżewski 2010; Marzęcki 2010; Wasilewski 2010]. Warto wskazać, że ustalenia sprzed dekady dobrze przystają do dzisiejszej sytuacji dyskursywnej, z tym że dochodzi do intensyfikacji niektórych cech dyskursu prawicowego. 
jest „romantyzm smoleński” [zob. Bagłajewski 2015]. Z tym nurtem recepcji romantyzmu wiążą Nowy Legion przynajmniej dwie kwestie: sięgnięcie po polityczny idiom Dziadów (melanż nawiązań zwłaszcza do Dziadów drezdeńskich) wraz z przejętą stamtąd ideą politycznego podziału narodowego (zapośredniczonego także przez Jakubowskiego prawdopodobnie od Rymkiewicza jako autora wiersza-manifestu romantyzmu smoleńskiego Do Jarosława Kaczyńskiego) [zob. Bagłajewski 2015: 204-214] oraz podkreślanie racji Polski prawicowej, odwołującej się do takich kategorii, jak naród („prawdziwy” naród), tradycja, polskość etc.

Chciałbym w tym miejscu wywodu przywołać opis i wnioski odnoszone do recepcji dziedzictwa romantycznego na prawicy poczynione przez Tomasza Platę, gdyż tendencje do romantyzacji polityki znalazły swoją wyjątkową wprost kulminację w romantyzmie smoleńskim. Krótko rzecz określając: po prawej stronie sceny politycznej „wykorzystano” romantyzm wolnościowy, tyrtejski do zasadniczego przeformułowania pojęć definiujących prawicowy projekt kulturowy: wyzyskiwano topikę i retorykę mesjanistyczno-martyrologiczną, by wzorem romantyków uwznioślić ofiarę, dać jej poczucie pełni życia w klęsce i cierpieniu. Zwłaszcza po katastrofie smoleńskiej podkreślano, że śmierć ma w sobie moc polityczną, może bowiem redefiniować wspólnotę narodową i jej cele (ściślej: rozpoznania dotyczą tej części wspólnoty, która w sensie politycznym manifestuje przez siebie zdefiniowaną problematykę etyczną, fundowaną na cierpieniu, ofierze, krwi niewinnie przelanej w imię słusznej sprawy, jaką jest umocnienie więzi państwowych). Smoleńskie reakcje zapewne inaczej by wyglądały, gdyby nie wcześniejsza działalność niektórych prawicowych intelektualistów. Dokonali oni bowiem, jak dowodzi Plata, zabiegu połączenia tradycji sarmackiej z romantyczną, odwołując się wyraźnie do stricte romantycznego wynalezienia sarmatyzmu. Sarmatyzm i romantyzm łączyć się zaczęły w manifestacjach dumy narodowej, fundowanej na mocarstwowym micie Rzeczypospolitej szlacheckiej, a także $\mathrm{w}$ romantycznym przefiltrowaniu owego zjawiska. Tym filtrem był misjonizm (jak się okazało, prowadził on do mesjanizmu), poddający apoteozie naród, który jako „przedmurze chrześcijaństwa” ma odnowić duchowo, moralnie zeświecczoną Europę. Można 
powiedzieć na marginesie, że hasła te uzyskują dziś szczególną wykładnię w oficjalnej propagandzie rządzącej partii: wystarczy włączyć telewizję publiczną, przerzucić prawicową prasę, by bez trudu wydobyć owo misjonistyczne przekonanie (z nieodłączną mesjanistyczną nutą) o duchowym odrodzeniu Europy, którego impuls ma wyjść z Polski. Nie wchodzę w dyskusję z tym poglądem - niebezpiecznie wszak bliskim narodowej megalomanii bowiem w swoim wywodzie raczej zwracam uwagę na opisowy charakter omawianego zjawiska niż na jego zalety, jak chcą jedni, czy niebezpieczeństwa, o których mówią inni [zob. Plata 2017: 33-6o].

Wróćmy do dramaturgii Jakubowskiego. Chciałbym wskazać, że diagnoza polityczna Nowego Legionu... powraca także w najnowszym utworze dramatycznym pisarza, czerpiącym na równi z Dziadów i Wesela (a także z Michela Houellebecqa, co zaskakiwać może tylko na pierwszy rzut oka), opublikowanym w roku 2017 w numerze „Dialogu” zatytułowanym Dożynki. Nie-komedia. Wedle deklaracji autora, chciał on napisać „współczesny dramat narodowy”, ukazujący wspólnotę „w stanie degradacji i rozproszenia” [Jakubowski 2017: 156] $]^{4}$ Swoją interpretację zacznę wszakże od utworu napisanego później, gdyż wówczas można będzie zauważyć utwierdzenie pewnych racji i postaw politycznych, we wcześniejszym utworze przywoływanych z romantycznej przeszłości nie tak jednoznacznie i deklaratywnie, jak w dramacie późniejszym. W takim odczytaniu Dożynki byłyby dramatem publicystycznego utwierdzenia racji, które w Nowym Legionie... zasnuwa widmowa rzeczywistość nieprzepracowanych narodowych traum. W zaproponowanej przeze mnie lekturze od ideowych, dość jednoznacznych rozstrzygnięć powracam do sfery narodowego mitu - naszych współczesnych „dziadów” w relekturze prawicowego pisarza - tam, gdzie „ciemno wszędzie, głucho wszędzie”.

Jakubowski napisał dramat nieprzystających do siebie racji poszczególne postaci rezonują wyraźnie rysowanymi dyskursami nacechowanymi ideowo. Wiele się tu więc mówi, niewiele się dzieje. W konstrukcji całości widoczne jest dość luźne nawiązanie do Wesela (obrzęd jako symboliczny wyraz istnienia grup społecz- 
nych w obrębie wspólnoty, przypominającej wszakże zbiorowość nie tyle z dramatu Stanisława Wyspiańskiego, ile raczej z filmu Wojciecha Smarzowskiego), ale w licznych fragmentach wyraźny jest także idiom Dziadów: na obrzęd przychodzą widma, „wywracając” dożynkową wspólnotę, która - koniec końców - okazuje się zdążającymi ku apokaliptycznemu końcowi „cząstkami elementarnymi” rozbitej zbiorowości. Diagnoza pęknięcia wspólnoty jest wyjątkowo wyrazista. Właściwie to wspólnoty już nie ma, są wrogie, mówiące „obcymi” językami obozy. Jakubowski pracuje w języku, ukazując nieprzystawalność poszczególnych racji, wybrzmiewających bez żadnego zakotwiczenia w jakimkolwiek wspólnotowym dyskursie. Postaci międlą frazesy, zderzają nieprzystające do siebie frazy i pochodzące z różnych rejestrów językowych strzępy dyskursywne, tworząc nacechowane ideologicznie „języki”. W Dożynkach lewicowy Kosmonauta - wyraźnie rysowany groteskową kreską - prowadzi dialog z Poetą - reprezentującym prawicowe racje, przeciwstawne do racji rozmówcy, choć także niepozbawione rozpoznania życia narodowego jako fantomowego istnienia (mówi: „Przegapiliśmy moment, kiedy dało się jeszcze coś uratować. Teraz zostały nam fantomy, fantazmaty, fantasmagorie. W sensie doczesnym przegraliśmy. Na całej, kurwa, linii” [D: 134]; pozostaje więc przenieść rojenia narodowe w zaświatowe rejony). Kosmonauta jest tu ośmieszany na całej linii. Sięgając po Norwidowską frazę, Jakubowski ukazuje nicowanie romantycznego patriotyzmu, nostalgicznego westchnienia do ojczyzny, „gdzie kruszynę chleba” podnosi się z ziemi, kontrowanego lewicowym lękiem przed „bogoojczyźnianym fetorem”:

Kosmonauta: Hjuston, mamy problem! [... ] Dotarłem chyba do kraju tego, gdzie powietrze jest paskudne i szkodliwe przez przywiązanie ludności do jadu trupiego. Czuję okropny bogoojczyźniany fetor, który szkodzi na drogi oddechowe. [D: 132]

W innym miejscu deklaruje:

KosmonAuta: Nie wierzę w duchy i nie wierzę w naród. Wierzę w instytucje. Wierzę w konstytucję. [D: 133] 
Na te słowa ripostuje Poeta („w zbroi i skrzydłach husarii”):

POETA: Demokracja polega na stopniowym gniciu wszystkiego, co w narodzie żywotne. Demokracja pozwala przetrwać szumowinom i zdrajcom, którzy w normalnych warunkach zawisnęliby na latarniach. [D: 133]

Pojawia się repertuar haseł politycznych dwu stron, z dobitnie wypowiedzianą diagnozą prawicową: „To, co nas podzieliło, to się już nie sklei” [D: 133], sformułowaną przez wieszcza prawicy, Jarosława Marka Rymkiewicza, z nieodłącznym fantazmatycznym marzeniem o „wieszaniu” jako akcie założycielskim „nowej Polski”. Jedna strona nie lubi takich słów, jak duchy, naród. Druga z kolei wedle Kosmonauty - „ryje w ziemi w poszukiwaniu”, a na pytanie „Czego”, uzyskuje co prawda odpowiedź Poety: „Prawdy i tylko prawdy” [D: 133]. Wybrzmiewa w tych słowach jedno z pojęć zaczerpniętych z prawicowego słownika politycznego, mianowicie „prawda smoleńska”. Autor stara się budować dramat racji, z nieodłącznym starciem ideowym jako fundamentem diagnozy politycznej współczesnej Polski rozdartej na dwa wrogie sobie obozy: tych, którzy kochają takie pojęcia, jak Polska, prawda, naród, i tych, którym Polska jest obojętna. Skąd my to znamy? Widzieć tu można nawiązanie do dramatu romantycznego: Dziadów części III czy przypomnianego przez Rymkiewicza Jakuba Jasińskiego [zob. Bagłajewski 2015: 208-210]. Zostały więc przywołane racje dwu uczestników sporu, ale czy autor rozdziela je równo? Czy może opowiada się wyraźniej po którejś ze stron? Mickiewicz w Salonie warszawskim przedstawił, jak pamiętamy, dwa obozy polityczne: patriotów i zdrajców, jednych jako reprezentantów „młodej” Polski zapaleńców patriotycznych i drugich jako reprezentantów „starej” Polski ugody i kolaboracji. Nie ukrywał, po której stronie jest racja ${ }^{6}$. Wyznaczył pewien model ideowy, chętnie dziś

5 Nawiązuję tu zarówno do tytułu i diagnozy zawartej w książce Jarosława Marka Rymkiewicza [2007], jak i do wyrazistych publicystycznie wypowiedzi poety i eseisty [zob. Wojda 2012; Woźniak-Łabieniec 2012].

6 W tradycyjnej mickiewiczologii wyraźnie wybrzmiewała teza o rezonerskim charakterze tej sceny [zob. Kleiner 1997: 330-336]. Ujęcie nowsze, akcentujące 
wykorzystywany przez prawicę, dokonującą znamiennej inwersji ideowej poprzez sytuowanie własnych racji jako zbieżnych z ideowym przesłaniem młodych zapaleńców. Jeżeli mielibyśmy wpisywać współczesne projekty polityczne w arcydramat, to przecież „młodzi” byliby raczej lewicową reprezentacją społeczeństwa, zaś „starzy” - prawicowo-konserwatywnym jego odłamem. Dziwne więc materii „pomięszanie” we współczesnych próbach aktualizacji idiomu politycznego Dziadów. Ale ponówmy pytanie: czy racje romantyczne dają się przenieść w niezmienionej postaci w rzeczywistość xxI wieku? Czy diagnoza Mickiewicza - innymi słowy - jest archetypicznym, ponadczasowym rozpoznaniem jakiejś esencji polskiego sporu, polskiego naznaczenia dziejowego ${ }^{7}$ ? Czy w wolnym i demokratycznym państwie można powielać rozpoznania z czasów zaborów?

Odpowiedź nie należy do skomplikowanych. Można owszem - niezmienione romantyczne diagnozy przenieść do współczesności, lecz będą one naznaczone piętnem anachronizmu historycznego, choć daje się usprawiedliwiać ów gest przeniesienia, tak jak próbował to czynić Rymkiewicz. Pisał on, chcąc obwołać Mickiewicza wieszczem posmoleńskiej prawicy: „Mickiewicz proponuje nam, żebyśmy, starając się zrozumieć nasze dzieje narodowe [...], brali pod uwagę, że istnieją (i może zawsze będą istnieć) Polacy, którzy kochają Polskę i są jej wierni - i jeszcze jacyś inni Polacy, którym Polska nie jest potrzebna" [Rymkiewicz 2010: 51]. Granicę między tymi dwoma „rodzajami” Polaków - i dwiema Polskami - wyznacza „konflikt między wiernością a zdradą” [Rymkiewicz 2010: 53]. Jaką „wiernością” i jaką „zdradą”, chciałoby się zapytać? Tego wprost się nie dowiemy, pozostajemy bowiem w sferze ponadczasowego modelu, który jakoby odkrył Rymkiewicz w swej lekturze politycznej Mickiewicza. Jakubowski podziela to rozpoznanie. Sięga więc po romantyzm, po Mickiewicza w taki sposób, jaki zaproponował Rymkiewicz - czytający bardzo szczególnie, bo ekscentrycznie i skrajnie przedmiotowo - diagnozę polityczną Mickiewicza, przykładając do romantycznego wieszcza jedno -

występowanie wśród towarzystwa salonowego większości postaci historycznych, prezentuje Ryszard Przybylski [1993: 206-208]. 
choć oczywiście ważne - rozpoznanie, wyprowadzone z Jakuba Jasińskiego i z jednej sceny Dziadów drezdeńskich. Przypomnijmy wszakże, iż podział na „czarne” i „białe”, bez oczywistego przecież niuansowania realnych postaw politycznych, potrzebny był Mickiewiczowi w tej konkretnej scenie do realizacji artystycznego zamysłu gry kontrastami wielkiego moralitetu i zarazem misterium, jakim są Dziady: walki dobra i zła, mającej wszak swoje metafizyczne usytuowanie, a nie tylko ziemską sferę zachowań politycznych ${ }^{8}$. U pisarzy prawicowych Mickiewicz został z kolei zredukowany do pewnego hasła, stereotypu politycznego. A gdzie Mickiewicz „całościowy” z Dziadów i nie tylko z tego dramatu: natchniony polityk z czasów prelekcji paryskich, twórca Legionu i autor Składu zasad, można by zapytać?

W rozmowie z autorem na łamach „Dialogu” - będącej pendant do dramatu - Jakubowski usiłuje przekonać czytelnika, że jako twórca Dożynek równo rozkładał racje, jakkolwiek nie zgadzał się z pewnymi przekonaniami postaci (szkoda, że nie wskazał, o które postaci chodzi i o jakie w istocie przekonania). Twierdzi, że pisał tak, by oddać racje milczącym, tym, którzy pozbawieni są głosu, owej niemej większości. To może być przecież gest polityczny - znamy nacechowaną empatią, lewicową rewindykację pozbawionych głosu. Ale po stronie prawicowej - czy ten sam gest znaczyć może: taki sam? Pytanie zaiste retoryczne. W prawicowym dyskursie ci, którzy ów głos odzyskują, szerzą często poglądy niebezpieczne: od nacjonalistycznego uwielbienia siły po rasistowskie i faszystowskie ekstrema. $Z$ nieodłączną potwarzą wobec tego, co określa się - niezbyt przecież sensownie łącząc dwa różne style myślenia - jako liberalno-lewacką zarazę i zaprzaństwo9. Wyostrzam ów przekaz - idąc za wzorem prawicowych dyskursów,

8 Teza ugruntowana w klasycznej mickiewiczologii [Niemojewska-Gruszczyńska 1920: 407 i n.; Borowy 1999: 359-362], odnowiona w książce Przybylskiego [1993]. Warto wskazać, że w całym dramacie owe postawy wyraźnie wykraczają poza binarny schemat sceny: są nie tylko „dobrzy” i „źli” Rosjanie, ale także ambiwalentnie ujęty lud; są „patrioci” i „zdrajcy” w Salonie warszawskim, ale np. w scenie I (więziennej) ukazana jest ambiwalencja postaw.

9 Na te „odgórnie narzucone definicje sytuacji, najczęściej w formie «czarno-białych» binarnych i uproszczonych obrazów”, wraz z nieodłącznym ekspresyjnym, wykluczającym przeciwnika słownictwem jako cechę charakterystyczną dla dyskursywnych podziałów IV RP zwraca uwagę Barbara Jabłońska [2010: 263]. 
formulowanych nie tyle w elitarnych kwartalnikach czy ośrodkach myśli, ile w propagandowym przekazie oficjalnym aktualnego obozu władzy, transmitowanym przez telewizję narodową, ochoczo podnoszonym przez internetowy lud o prawicowych inklinacjach. Czy więc milczący, jeśli udzielić im głosu, przemówią tak, jak chciałby Jakubowski, czy jakoś inaczej? Ważąc racje, czy wykrzykując hasła? Upominając się o siebie i Innych: wykluczonych, pozbawionych ojczyzny, szukających sensu życia w lepszym świecie - czy zbierających się wokół wodza, aby potwierdzić wspólnotowe rozpoznania życia narodowego w wykluczeniu Innego z obrębu jednoznacznie definiowanej wspólnoty plemiennej?

Jakkolwiek więc Jakubowski stara się balansować na cienkiej linii, oddzielającej groteskowe wyostrzenie lewicowego dyskursu (lewackiego - wedle upowszechnianego na prawicy ujęcia ideologii nie-prawicowych - takiego określenia używają w utworze antagoniści) od prawicowej apoteozy narodu, dyskursu akcentującego narodowo-wspólnotowe wartości ${ }^{10}$, niewolnego wszakże od pewnego dystansu wobec formułowanych ocen, to diagnoza podzielonej społeczności, niemożności uzgodnienia racji, sporu prowadzącego nie do wyznaczenia przestrzeni agonu ideowego, lecz do wojny dwu Polsk", utwierdza ów romantyczny anachronizm historyczny. Zauważyć bowiem nietrudno, że inna ekspresja słowna określa „lewackie” argumenty, ubierane w kostium karykatury i wynaturzenia, podkreślane stylistyczną szarżą mortualistyczną, inna zaś argumentację „prawdziwych” Polaków, których reprezentantem jest Poeta, mówiący w jednej ze scen: „Lewactwo to lewactwo. Lewactwo to wróg wolnych Polaków. Nie ma z nim rozmowy" [D: 132]. Co prawda Poeta „zdradza” jakby mimochodem marzenie swej strony politycznej, która chce pokonać przeciwnika nie tylko dyskursywnie (podobnie chciałby to uczynić antagonista), słowami nacechowanymi emocjonalną stylistyką walki ${ }^{12}$ - stąd więc wynika

10 Jest to, zdaniem Bartmińskiego [2010: 18], kluczowa cecha dyskursu narodowo-prawicowego.

11 Potwierdzają to badania socjologiczne [zob. Giza 2013: 105-145].

12 Na stygmatyzację przeciwnika, demonizację życia publicznego, łączoną z populistycznym systemem wartości w perspektywie walki, zwraca uwagę w bogatym materiałowo artykule Stanisława Niebrzegowska-Bartmińska [2010: 349-355]. 
przemoc językowa jako substytut (czy zapowiedź?) innej przemocy. Pojawia się pragnienie anihilacji przeciwnika. Dodajmy na marginesie, że prawicowe fantazje o zniszczeniu drugiej strony ujawniają także utajone źródła słabości, oparte na lękowym podłożu słabej podmiotowości, nicujące tym samym owe sny o potędze. Jedna z postaci wszak mówi: „I dlatego tak głośno krzyczymy, że jesteśmy narodem, bo się tak naprawdę nie poczuwamy do polskości" [D: 127].Jeśli tak, dziwna to diagnoza „prawdziwej” polskości, choć nietrudno dostrzec, że jakoś prawdziwa. Ukryta pod powierzchnią buńczucznych słów o sile, ukazująca ciemną magmę niewykrystalizowanej w istocie formy narodowej.

W narodowym obrzędzie - w którym Bachantki (przywędrowały one z mroku dziejów, jakiegoś greckiego praobrzędu), sięgając po Mickiewiczowskie zaklęcia, ukazują, jak pęknięte są te współczesne „dziady”, jak „święto nas wszystkich” [D: 145] oddaje głębokie wspólnotowe podziały [zob. Kosiński 2013; Siwicka 2013] - ujawnia się, przywołany także w Nowym Legionie..., pewien „ciemny” nurt polskich dziejów, których kwintesencją są „dziady”:

\section{Ciemno wszędzie}

Głucho wszędzie

Straszno było jest i będzie

Upiór idzie po ugorze

Ale nigdzie dojść nie może

Więc wołajmy: hej upiorze!

Zachodź do nas w imię boże

W boże imię czy nieboże

Na dożynki przyjdź upiorze [... ]. [D: 142]

Dla jednych źródłem podziałów będzie nieustający spektakl „nieszporów przy grobach” [D: 145], gdy „nieustannie ekshumowani”, „muszą żyć nawet po śmierci” [D: 147]; to są - o ironio! także polskie „dziady”, archaiczne i anachroniczne przywoływanie 
umarłych do świata żywych, kiedy „polska wieczna mgła [... zamazuje właściwy ogląd rzeczywistości” [D: 147]. Inni z kolei - ich krytykiem będzie Biskup, milczący aż do finału dramatu, przemawiający ustami Didżeja w wielkiej tyradzie, będącej fundamentalną krytyką kapitalistycznej współczesności - hołdują bożkowi materializmu jako zasadzie funkcjonowania świata. Padają m.in. takie słowa:

Szatan zorganizował światowy zjazd demonów. W swoim przemówieniu na wstępie powiedział: [... A co najważniejsze trzeba zaszczepić w nich pragnienie dóbr materialnych, chęć wzbogacania się - i służenia dla mamony. [...] A gdy będą zapaleni pragnieniem osobistego wzbogacenia się, pogonią za mamoną - nie będzie im już wtedy potrzebny Chrystus. [D: $152-153]$

Dalej mowa jest o poświęceniu całej swej egzystencji pracy jako zasadzie współczesnego zmaterializowanego świata - po to, by mieć więcej i więcej. Ważną rolę w owej stymulacji na pracę i powierzchowną rozrywkę mają odgrywać media elektroniczne. Następnie mówi się o zatarciu religijnego charakteru świąt chrześcijańskich i wreszcie czas na podsumowanie namiętnego oskarżenia współczesności oddanej w pacht diabłu:

Zalejcie ich życie tak wieloma pozornie dobrymi rzeczami, żeby nie mieli czasu na zastanowienie się nad poszukiwaniem pomocy u Jezusa, a wkrótce będą żyć i pracować, opierając się tylko na sobie, poświęcając swoje zdrowie i rodziny.

To działa! To wspaniały plan! [D: 154]

W końcu więc katastrofa i Dożynki staną się politycznym dramatem katastroficznym, niczym współczesna Nie-Boska komedia, nieprzywołana tu wprost, ale przecież stale obecna pod powierzchnią zdarzeń, by wypłynąć w finale. Bachantki, w swym ostatnim wystąpieniu, w kontekście finałowej sceny tańca, będącej nawiązaniem do tańca i z Wesela, i z orgiastycznych obrzędów, podkreślają apokaliptyczne rozpoznania zmierzającej ku zagładzie współczes- 
ności, poszerzając - jak się wydaje - nawiązania do Nie-Boskiej komedii odniesieniem do prozy Houellebecqa (Czastki elementarne, Możliwość wyspy):

W obliczu końca nieodwołalnego

[...]

Tańczmy na gruzach świata znanego

$[\ldots]$

Niech dom postrada fundamenty

Niech nic już nie będzie święte

Niech otworzy się otchłań

Ostatecznych rozstań

I żadnych więcej przesłań

Tylko cząstki w kosmosie rozrzucone

Każda pędząca w swoją stronę

Każda na samotność skazana

Oj ta dana!!! [D: 154-155]

Finał Dożynek, w apokaliptycznym rozpoznaniu świata zdążającego ku zagładzie, to oddanie racji wizji - będącej czynnikiem odsyłającym poza ułomne, cząstkowe argumenty dwu stron politycznego sporu - jako elementowi godzącemu wyrażone sprzeczności. Wizja jest artystycznym pogodzeniem racji na innym poziomie niż światopoglądowy spór, ponieważ ukazuje ów spór jako w istocie bezprzedmiotowy - wobec ostatecznej zagłady samotnych „cząstek elementarnych" ludzkości, wirujących w kosmosie.

Wróćmy do Nowego Legionu... i zawartej w nim oceny naszej współczesności - kontrowanej Mickiewiczowską obecnością i nieobecnością, powrotami pośmiertnymi wieszcza i stworzonych przez niego postaci, które, jak się okazało, są czymś więcej niż bohaterami literackimi. Nawiązanie do dramatu Wyspiańskiego, będącego wielką glosą mesjanistyczną, próbą odpowiedzi na pytanie: czy do nowego życia Polski konieczna jest jej mesjanistyczna śmierć, czy wydobycie na powierzchnię pierwiastków witalistycznych - nie do końca się uobecnia w warstwie zdarzeniowej dramatu Jakubowskiego. Autor Nowego Legionu - wymijając tak istotny i dla znaczeń dramatu Wyspiańskiego kluczowy moment polemiczny, jakim jest 
debata wokół mesjanizmów Krasińskiego i Mickiewicza - skupia swoją uwagę na tej sferze znaczeń, która w utworze autora Nowego Legionu wiąże się z interpretacją Mickiewiczowskiego podążaniu ku misterium śmierci. Jak się wydaje, Jakubowski nawiązał do imaginarium Mickiewiczowskiego w znacznie szerszym zakresie niż do dramatu Wyspiańskiego. Stamtąd wszakże przywędrowała zasadnicza ideowo konstrukcja reakcji Mickiewicza - jako osoby dramatu - na aporie rzeczywistości opierającej się narzucanej przez wielkiego ducha idei. U Wyspiańskiego:

Przezwyciężenie oporu świata może nastąpić tylko za cenę osobistej klęski - a przepowiadane zwycięstwo dotyczy jedynie idei, która przeżyje swego chorążego i przetrwa noc panujących zbrodni. Mickiewicz, bohater tragiczny Legionu, nie cofa się przed całopaleniem. [Nowakowski 1989: LV]

Prowadzi swych wyznawców na łódź śmierci. Czy tak jest u Jakubowskiego? Tym, co zwraca naszą uwagę, są powtarzające się śmierci bohatera - wielokrotne i pozorne, skoro powraca on wciąż w nowych sytuacjach historycznych ${ }^{13}$. Oznacza to, że dzieje nasze może osnuwać jakaś skaza ontologiczna - skoro tyle śmierci Mickiewicza nie prowadzi do „nowego życia”, co zapowiadali wszak romantycy w latach 40. XIX wieku: twórca Legionu i Krasiński jako autor Legendy [zob. Bagłajewski 2009: 339-344]. Krasiński ignorował sferę rzeczywistości, przenosił swój mesjanizm w zaświatowe rejony. Z kolei Mickiewicz konkretyzował go ideą realnego przekształcenia świata. Ale ostatecznie twórca historycznego Legionu w wykładni Wyspiańskiego wpisywał swoją misję w symbolikę męczeństwa i odkupienia [por. Prussak 1993: 45-54]. Spróbujmy

$13 \mathrm{~W}$ polemicznej interpretacji Wiktora Weintrauba wobec uwznioślająco-heroicznych odczytań Legionu zwraca uwagę podkreślenie upiorowatej egzystencji Adama Mickiewicza w życiu duchowym Polaków w wizji Stanisława Wyspiańskiego: „Mickiewicz jest groźnym upiorem politycznego mistycyzmu, wysysającego siły żywotne narodu, prowadzącego ludzi w śmierć i zagładę w imię haseł równie wzniosłych, co nieosiągalnych” [Weintraub 1957; cyt. za: Nowakowski 1989: LXII)]. Z takim poglądem zapewne po części zgodziłby się Jarosław Jakubowski w swej interpretacji upiora-Mickiewicza. 
więc nieco bliżej spojrzeć na problematykę tanatyczną Nowego Legionu... jako kluczową sferę przywołanej tu symboliki narodowej.

W prologu dramatu Upiór objawiający się w naszej współczesności - „Na świecie jeszcze, lecz już nie dla świata”, zgodnie z formułą z II części Dziadów - zamierza opowiedzieć o „śmierciach” Mickiewicza, z których wieszcz powstawał do kolejnego widmowego wcielenia w polskich dziejach. Przy czym warto powiedzieć, że w „przemieszaniu” czasów i postaci jedna tylko śmierć odnosi się do czasów Mickiewicza - przywołany jest towianistyczny okres biografii poety - natomiast inne „dzieją się” współcześnie: w latach „dwa zero któryś”. To w tę bliską nam współczesność, powiedzieć można w czas III RP, wkraczają romantyczne duchy i upiory, które materializują się w naszych dziejach. Polska historia staje się widmowym powrotem do nieprzepracowanych romantycznych traum, jakby Polacy już stale byli w nich uwięzieni. Kolejną matrycą tekstową Dziadów wyzyskaną przez Jakubowskiego jest przeformułowany Mickiewiczowski podział na „dwie Polski”, przyjmujący $\mathrm{w}$ dramacie postać dychotomii: wykluczeni kontra elita [zob. Kopciński 2016: 261].

Pierwsza śmierć Adama jest przeniesieniem we współczesne realia „wieszcza narodowego”, ujawniającego wrażliwość podobną do tej, którą zawarli w swych utworach prozaicy polskiej prowincji czasów transformacji: Mariusz Sieniewicz i Dariusz Odija, ukazujący realia Polski post-PGR-owskiej. Mickiewicz utożsamia się $\mathrm{z}$ wykluczonymi w ich beznadziei codziennego bytowania:

A w domach - co tam widzę? - ni jednej pociechy,

Jednego przytulenia, tylko łóżka też szare, [...

Ale choć ciasno - pusto, pustką rezygnacji,

Która pozwala tylko na życie z dnia na dzień, [...]. [NL: 287]

Ludzka nędza przeciwstawiona jest pańskim klimatyzowanym gabinetom, zaś reprezentantem współczesnych krwiopijców ludu jest Puttkamer, wysyłający zresztą w finale sceny na tamten świat Mickiewicza (ten bowiem romansuje z trzpiotowato-głupkowatą Marylą; takie przedstawienie słynnej muzy wyraźnie 
przenosi scenę do sfery odniesień komediowych). Wieszcz jest tu więc kimś w rodzaju barda zapomnianej prowincji czasu transformacji ustrojowej, biednych dziatek i ich rodziców, żyjących w szarej rzeczywistości, pozbawionych nadziei na zmianę swego losu. Czym jest ta śmierć Mickiewicza w tak kreślonym obrazie świata? Trudno jednoznacznie odpowiedzieć. Być może „pierwsza śmierć” wieszcza, podkreślając diagnozę polityczną zbyt dużych kosztów społecznych transformacji, ma wypowiedzieć współczesną niezgodę na wykluczenie jednych i zbudowanie na ich krzywdzie „pałaców” beneficjentów systemu, ma odsłonić przy tym jakąś bezwyjściowość sytuacji społecznej? Może ma wskazywać jeden z „grzechów”/błędów podstaw III RP? Ale czy to prawicowa diagnoza, czy zaanektowane przez prawicę lewicowe rozpoznanie? Odpowiedź przyniosą kolejne sceny „śmierci” Mickiewicza.

W Drugiej śmierci Adama obok bohatera, Upiora, pojawia się Konstancja Łubieńska - zaś poeta, jakkolwiek kontestuje system w scenie wyraźnie stylizowanej na Salon warszawski (jest tu towarzystwo stolikowe „z przekąskami i winem grono aktorów, reżyserów, literatów, krytyków, dziennikarzy”, wśród nich zaś Maestro - wybitny, choć powielający swą niegdysiejszą wielkość reżyser, udekorowany orderem pieszczoch władzy; z kolei „Bliżej drzwi grupka młodzieży” [NL: 291]), jakkolwiek chce iść do młodych kontestatorów, to Konstancja skutecznie prowadzi go w inną stronę: do grupy stolikowej. Mickiewicz jest poetą zawieszonym między tymi dwoma światami, pragnie radykalnego gestu, ale boi się go wykonać. Wszakże do czasu. Omawiana scena jest transpozycją Mickiewiczowskiej diagnozy $\mathrm{z}$ arcydramatu: towarzystwo stolikowe chwali film Maestra, może bowiem przejrzeć się w jego uładzonej wizji rzeczywistości. Jednakże zdaniem Mickiewicza dzieło mistrza jest „ciemnym zwierciadłem”, zaś Mickiewicz-powrotnik zna drugą stronę „polskiego zwierciadła”, czyli świat różniący się od tego z dzieła Maestra, jak wolno sądzić: polskiej biedy i wykluczenia, na której zbudowano bogactwo „nowych” elit:

Tam świat nie-przedstawiony!

Film to wielki, film-tworzenie, 
Taki film jest siła, dzielność,

Taki film jest nieśmiertelność! [NL: 292]

Język Wielkiej Improwizacji, jego potencjał rewizyjny, ma wskazać inną diagnozę rzeczywistości, konkurencyjną wobec tej, którą stworzył w swym chwalonym dziele Maestro:

Daję ci bohatera - on przyszedł z ciemności, /

On długo cierpiał, długo, on był niewolnikiem, [... ]. [NL: 293]

Ów bohater stylizowany jest na kogoś, kto przegrał w polskich przemianach, jest on kimś, kto „patrzył bezsilnie, jak wszystko w co wierzył, / W senny koszmar się zmienia” [NL: 293]. To oczywiście diagnoza polskiej prawicy o początkach przemian po roku 1989. W optyce cytatów z Dziadów, wyzyskiwanych instrumentalnie przez Jakubowskiego, Mickiewicz jest ni mniej, ni więcej poetą współczesnej prawicy, w tym sensie, że dzieli z nią kontestację demokratyczno-liberalnego porządku jako systemu opartego na ludzkim nieszczęściu. Znów - zamiana pojęć? Zaanektowanie haseł lewicowych przez pisarza prawicowego, biorącego w obronę pokrzywdzonych przez polską transformację? Skoro lewica okazała się nieskuteczna, to prawica „przejmuje” jej hasła i postulaty? Zawłaszcza język? Tak by to wyglądało, wszakże i lud jest tu na dwoje rozłamany. Z jednej strony są cisi, porzuceni, oszukani przez nowe elity, z drugiej - lud ogłupiony ideami nowego porządku: kapitalistycznego w dziedzinie ekonomii, „lewackiego”, jak się go nazywa, w sferze ideologii. Taką grubą kreską rysuje swą diagnozę społeczno-polityczną dramaturg. Dobrze to widać w dialogowej polemice Maestra z Mickiewiczem. Ten pierwszy mówi, że jest Historią, bo on ją w swych dziełach stworzył, nadał jej formę. Mickiewicz z kolei deklaruje: „Lecz wiedz, że ja wrócę, / Upiorem lub majakiem, wrócę na twój pogrzeb, [...]” [NL: 294]. Z jednej więc strony mamy sztukę uładzoną, fałszywą, z drugiej zaś świat niewypowiedziany, milczący: szerokich mas, stłamszonych, ale też grożących rewoltą. Konsekwencją sztuki Maestra, kwestionującej kontrasty rzeczywistości, opartej na ułudzie sytych i zadowolonych elit, nie jest wszakże bunt poszkodowanych przez reformy, lecz 
nihilistyczna emancypacja pewnego odłamu ludu. Jakubowski chce pokazać inną stratyfikację społeczną, zbieżną z „posmoleńskim” rozpoznaniem. W tle sceny „salonowej” „burzy się, miota, dziki tłum" na ulicy. Ale ten tłum to nie uosobienie Polski, lecz pochód błazeński - jak konstatuje Mickiewicz:

Na czele niosą bożka z gazet i śliny,

$[\ldots]$

Tłuszcza staje pod krzyżem ... Zrzuca krzyż na asfalt!

I w miejsce krzyża wśród śmiechów ustawia bałwana!

A teraz szczają, szczają! Prosto na krucyfiks! [NL: 296]

Bluźnierczy gest, odsyłający do znanych scen z Krakowskiego Przedmieścia, jest więc potępiany autorytetem Mickiewicza. Są te sceny odwrotną stroną - owym bluźnierczym karnawałem romantycznej mszy patriotycznej, jaką stały się inne performatywne wydarzenia, aktualizujące romantyczny obrzęd narodowy na Krakowskim Przedmieściu. To tam znajdował się „prawdziwy” lud. Nie musiał o tym pisać Jakubowski, wystarczy, że zrobili to za niego inni: twórcy i wyznawcy romantyzmu smoleńskiego. Lud nihilistycznej agresji i lud smoleńskiej religii - oto kolejne „pęknięcie”, rów tektoniczny współczesnej Polski. W swej diagnozie socjologicznej, że tak ją nazwę, dramaturg ukazuje więc podziały społeczne biegnące w różnych kierunkach, obejmujące nie tylko tradycyjne klasyfikacje na „elity” i „lud”, lecz także w swym dalszym zróżnicowaniu - na kolejne grupy. Współczesne polskie „dziady” mają, jak widzimy, w dramacie Jakubowskiego różne oblicza i jakkolwiek owo bluźniercze jest potępiane, i dokonuje owego aktu potępienia sam Mickiewicz, to prawda o „dwu Polskach” dramatycznie sobie obcych wybrzmiewa w tej scenie donośnie. Oczywiście - jak to u prawicowych pisarzy - jedna strona ma cechy wyłącznie niemal diaboliczne, zaś narodowe zaprzaństwo przybiera tu postać sztuki „lekkostrawnej”, „łatwej do przełknięcia” (z wypowiedzi Maestra [NL: 296]), wymijającej istotne konflikty współczesności. Druga strona - wzmacniana autorytetem Mickiewicza, choć powiedzieć trzeba, że dość dwuznacznym, skoro cechą jego charakteru jest niezdecydowanie, wahanie - w narodowym 
patosie jest wzniosła i zdolna ujawnić sens cierpienia, zgodnie $\mathrm{z}$ wielką frazą przywoływaną $\mathrm{w}$ dzisiejszym dyskursie prawicowym: „Patrzcie, $[\ldots]$ patrzcie, przyjaciele, / Otóż to jacy stoją na narodu czele” - „Powiedz raczej: na wierzchu. Nasz naród jak lawa [...]” [Mickiewicz 1995: 209].

Polskość jest w dramacie Jakubowskiego snem, brzemieniem trudnym do udźwignięcia, zadaniem, majakiem prześladującym polskich emigrantów aż po krańce ziemi. Nieme widmo, błąkające się w opowiadanych snach, nie może uleczyć chorych dusz, nie da zapomnieć o ziemi, która jest ziemią jałową, domem umarlych. Mickiewiczowski dwuwiersz, pojawiający się jako refren Chóru "Ciemno wszędzie, głucho wszędzie, / Co to będzie, co to będzie?” [NL: 300-301] - wprowadza aurę tajemnego obrzędu, ujawnienia tego, co skrywane głęboko, co nie pozwala wyrwać się z zaklętego (i przeklętego) kręgu polskich spraw.

Z przedstawianą diagnozą polskiej współczesności wiążą się także inne „śmierci” Mickiewicza. I tak w Czwartej śmierci Adama biograficzna transpozycja sceny z audiencją Mickiewicza u papieża, zapośredniczona przez inne media romantyczne - zwłaszcza Kordiana i legendę biograficzną wieszcza (przede wszystkim Legion Wyspiańskiego) - ukazuje bezsilność dostojnego starca i Mickiewiczowskie pragnienie przekształcenia świata, wielkiej, rewolucyjnej zmiany, której ma dokonać Legion. Mickiewicz chce papieskiego błogosławieństwa, cóż, kiedy zmęczony i przerażony papież rejteruje do lóżka.

Wieszcz w namiętnych tyradach nie godzi się na współczesne upodlenie, na niewolnictwo Polaków, mające swe źródło w zagubieniu duchowej busoli. Oto próbka dramatycznego starcia, w którym papieskie racje są trywializowane w materialistycznych diagnozach, zaś Mickiewiczowskie - ujawniają potencjał wywrotowy:

PAPIEŻ

Czy twój kraj nie jest wolny?

MICKIEWICZ

Nie, ojcze! My cierpimy! Wsiądź do autobusu

Albo wyjdź na ulice - ujrzysz niewolników

$\mathrm{Z}$ twarzami jak pieczęcie aktów desperacji. 
PAPIEŻ

Co zatem was niewoli? Bieda? Korporacje?

Pewnie banki! Kredyty? Umowy śmieciowe?

MICKIEWICZ

To są okoliczności, czyli rzeczywistość.

Prawdziwy wróg gdzie indziej szykuje nam zgubę.

PAPIEŻ

Cóż to za wróg śmiertelny czyha na człowieka?

MICKIEWICZ

Bieda, rozpacz i nuda! [NL: 314$]$

W taki sposób, zdaniem Jakubowskiego, rozmawiałby dziś Mickiewicz z papieżem. Inna kwestia, że akurat argumenty Mickiewicza $\mathrm{z}$ dramatu podnosi dziś papież Franciszek. To w jakimś sensie unieważnia trafność diagnoz społeczno-politycznych u współczesnego dramaturga. Wróćmy wszakże do utworu. Rewolucjonista Mickiewicz chce pokazać światu, że stworzony przez niego Legion da ludziom nadzieję, pozwoli człowiekowi, który „przestał znaczyć / Coś więcej niż numerek w zimnej statystyce” [NL: 315], stać się podmiotem historycznej zmiany, co zresztą podkreślał Jakubowski w rozmowie zamieszczonej w „Dialogu”. Posłuchajmy, jak Mickiewiczowskie interteksty (wzmacniane frazą z Miłosza) łączą się z marzeniem polskiej prawicy o rewolucji, której symbolem miałoby być wysadzenie Pałacu Kultury:

\section{MICKIEWICZ}

W każdej wsi i miasteczku przyłączą się nowi,

Będziemy jak lawina, co zrywa skorupę

I zstępuje do głębi, tam gdzie dusza polska

Kisiła się w gnuśności. My damy jej wolność!

Gdy staniemy w Warszawie, będzie nas milion

I będziemy tam stali milczący, cierpliwi,

Tak długo, aż otworzą dla nas bramy Sejmu,

Ministerstw, szkól, urzędów, uniwersytetów.

A jeśli nas nie wpuszczą, wejdziemy tam sami. [NL: 315-316] 
Ale Mickiewicz - współczesny bard rewolucji - poniesie klęskę. Jego Legion, do którego przystąpi dwójka bezdomnych, zamkniętych później w domu dla obłąkanych, rozwieje się jak dym. Można przywołać słowa Wiktora Weintrauba [1998: 40], który pisał o Mickiewiczowskim przedsięwzięciu, odnosząc je do dramatu Jakubowskiego: „Sławny Legion Mickiewicza był patetycznym i donkiszockim przedsięwzięciem”. Wszakże zredagowany dla Legionu Skład zasad, jak dowodzi Weintraub (przypominający klasyczne rozpoznania Stanisława Pigonia), był w zasadzie kwintesencją polityki Mickiewicza. Jakkolwiek mowa w nim o martyrologii i wstającej z grobu Polsce, to dalej znalazło się znamienne odejście od mesjanistycznie rozumianej polityki, swoisty potencjał rewindykacyjny, do którego mogą odwoływać się pisarze współcześni (zarówno z lewej, jak i prawej strony): wolność wyznania, równouprawnienie wszystkich obywateli, w tym kobiet i Żydów, ale jak zauważono, Mickiewicz wikła się w sprzeczności, które wymija, tworząc utopię, jak ją określił ironicznie Weintraub [1998: 43]: „społeczne Eldorado”, ukazujące „żenującą niezdolność myślenia w kategoriach konkretnych warunków społecznych”. Te słowa dałoby się odnieść do wyprowadzonej z projektu Mickiewicza współczesnej jego repetycji, sprowadzanej do jednego hasła: rewolty ludowej, jakiejś zapowiadanej zemsty za lata ciemiężenia i uprzedmiotowienia. Jednak to hasła - tylko hasła - wyprowadzone nie z repertuaru idei politycznych Legionu Mickiewicza, ale raczej z wąskiego ich aspektu, jednej w zasadzie propozycji programowej. A to za mało, by przywołana z czasów romantyzmu idea Legionu mogła rezonować inaczej niż karykatura wielkiego, mimo wszelkich słabości i aporii, zamysłu ${ }^{14}$.

Idea Legionu wróci wszakże po jakimś czasie, wraz z wybudzonym ze snu-śmierci Mickiewiczem, w Szóstej, ostatniej śmierci Adama której akcja toczy się w ośrodku terapeutycznym „Świt” w Borach Tucholskich. Scena ta zawiera liczne intertekstualności romantyczne reminiscencje wirują tu w rytmie krótkich, urywanych dialogów postaci. Pacjent-Konrad przypomni formułę Chóru z Dziadów części II. Pacjentka-Maryla zamieni się w Guślarza, 
przyzywającego duchy „z głębin czasu” [NL: 326], zaś w dialogach pacjentów i duchów, odbywających się zgodnie z autorską wskazówką symultanicznie, co rusz rozbrzmiewają Mickiewiczowskie cytaty. Pacjentka II skarży się, niczym Karusia z Romantyczności, że jej matka po utracie pracy „także była sama, / W tłumie samotnych ludzi, w wielkim, zimnym mieście” [NL: 328]. Rytmicznie wraca fraza: „Ciemno wszędzie, głucho wszędzie....”

Mickiewicz - kolejny już raz - stara się wybudzić pacjentów, usypianych lekami na chorobę zwaną Polską, do działania. Jakby niezależnie od „śmierci”, które są jego powtarzalnym losem, tak jak rytmiczne są powroty do działania w realnym świecie - budzenie do polskości było jego jedynym zadaniem. Polskość ta wszakże dostępna jest w letargicznym, widmowym doznawaniu ,ja”, błądzącego niczym duch-powrotnik. Mickiewicz chce, by Polacy ujrzeli swoją nędzę, małość i zapragnęli na dnie tej nędzy wzbić się do działania. Oczywiście, zdaje się Jakubowski mówić, jak zawsze, takie rewolucyjne pragnienia wzbudzają kontrę ludzi „rozsądnych" (a przeciwstawienie ludzi rozsądnych ludziom szalonym jest $\mathrm{w}$ dramacie kolejnym zapożyczeniem Mickiewiczowskim, z waloryzacją szaleństwa, zdolnego przemienić płaską rzeczywistość na działanie duchowe, odmieniające świat). Diagnoza jest prosta: trzeba wrócić do utraconych, romantycznych źródeł „prawdziwego” patriotyzmu. Do kraju tego...., choć jest on raczej widmowym marzeniem z przeszłości niż rzeczywistym doznaniem czasu teraźniejszego.

Oto dłuższy fragment:

\section{UPIÓR-PIELĘGNIARZ}

Rok mamy który? Dwa zero... nieważne.

On sam tam leży, przypięty pasami

Do twardej pryczy, karmiony przez rurkę...

PACJENT-KONRAD

Gada do siebie, opowiada baśnie

O jakimś kraju, dalekim i dawnym...

PACJENTKA-MARYLA

Mówi o chlebie, że smakował lepiej,

A przed krojeniem krzyżem go znaczono... 


\section{PACJENT II}

I nawet okruch się tam nie zmarnowat.

Co nie zjadł człowiek, bydlęciu dawano.

$[\ldots]$

\section{PACJENT III}

A w tęgie zimy pito mleko z miodem,

A miód był z kwiatów, co rosły na łąkach ...

$[\ldots]$

\section{STARY}

A Bóg był ojcem, a ojczyzna matką ...

\section{PACJENT-KONRAD}

Ten kraj nie zginą - mówi on spętany Tylko utracił swoją twarz prawdziwą, Tak długo krzywił ją w ciągłej tresurze Sztucznych grymasów, że stała się maską. [NL: 336]

Retrospektywna utopia? Utkana z romantycznych intertekstów: Norwida, Pana Tadeusza, czytanego w kontekście staropolskiej idylli ziemiańskiej ${ }^{15}$. Ale to przecież szlachecki raj-Soplicowo. Czy jest tu miejsce na lud, o który jakoby upomina się „Mickiewicz” Jakubowskiego? Jednak korektę - pytanie otwarte - wprowadzają tu złowieszcze słowa Chóru, umieszczone po tej sielskiej scence: „Ciemno wszędzie, głucho wszędzie, / Co to będzie, co to będzie?" [NL: 337]. No właśnie - co?

Mickiewicz - nieobecny na scenie, przywiązany do szpitalnego łóżka - odgrywa swą rolę budziciela narodowych sumień: „Mówił: «wstańcie, idźcie»" [NL: 338]. I tak się stanie. Scenę wieńczy bunt pacjentów, mający przecież swoje potwierdzenia nie tylko w dziełach romantycznych, ale także w kulturze współczesnej (i w popkulturze filmowej). Być może Legion powstanie do działania?

W Epilogu - wzorem Prologu - pojawia się upiór, ukazując, że historia jest niezakończona: że bohater, który umierał sześć razy, może jeszcze wrócić, niczym postać w grze komputerowej, podobnej jakoś do narodowego mitu, czytanego współcześnie:

15 Bardzo ów idylliczny rys Pana Tadeusza podkreślała Alina Witkowska [1998: 160-173], pisząc o arcypoemacie jako „zakątku raju”. 
Więc był bohater, miał imię i Sprawę,

Miał też gruczoły, co było ciekawe

$\mathrm{Z}$ punktu widzenia dramaturgicznego.

Chciał tu mieć Legion, Legion dobrych ludzi,

Temu poświęcił wszystkie swoje życia

I wszystkie śmierci. Czy mu się udało?

I gdzie jest teraz? Odpowiedzcie sobie,

Pomyślcie o tym, byle nie za długo,

Bo czasu mało, coraz mniej w klepsydrze...

Uhu... [NL: 341]

Złowieszczo zabrzmiało to „Uhu ...”. Znaczy, że jeszcze powróci.

\section{Bibliografia}

Bagłajewski Arkadiusz (2009), Poezja „trzeciej epoki”. O twórczości

Zygmunta Krasińskiego w latach 1836-1843, Wydawnictwo UMCs, Lublin.

Bagłajewski Arkadiusz (2015), Czy istnieje „romantyzm smoleński”?, w: tegoż, Obecność romantyzmu, Wydawnictwo UMcs, Lublin, s. 195-214.

Bartmiński Jerzy (2010), Język IV RP, czyli o karierze przecieku. Problem wiarygodności dyskursu publicznego, w: Język IV Rzeczypospolitej, red. Maciej Czerwiński, Paweł Nowak, Renata Przybylska, Wydawnictwo umcs, Lublin, s. 7-31.

Borowy Wacław (1999), O poezji Mickiewicza, wyd. 2 uzup., Towarzystwo Naukowe KUL, Lublin.

Czyżewski Marek (2010), "Język wrogości” oraz spór o III i IV RP $w$ perspektywie analizy dyskursu publicznego. Wybrane rezultaty projektu badawczego oraz uwagi metodologiczne, w: Język IV Rzeczypospolitej, red. Maciej Czerwiński, Paweł Nowak, Renata Przybylska, Wydawnictwo UMCs, Lublin, s. 47-61.

Giza Anna (2013), Dwie Polski o dwóch Polskach, czyli samoreprodukujący się dyskurs, w: Gabinet luster. O ksztattowaniu samowiedzy Polaków $w$ dyskursie publicznym, red. Anna Giza, Scholar, Warszawa, s. 105-145.

Jabłońska Barbara (2010), Językowe podziały rzeczywistości społeczno-politycznej IV RP, w: Język IV Rzeczypospolitej, red. Maciej Czerwiński, Paweł Nowak, Renata Przybylska, Wydawnictwo uMCs, Lublin, s. 257-269. 
Jakubowski Jarosław (2014), Posłowie, w: tegoż, Generał i inne dramaty polityczne, ADiT, Warszawa, s. 376-379. (Skrót: NL)

Jakubowski Jarosław (2017), Odwróciłbym Bernharda. Rozmowa z Jarosławem Jakubowskim, „Dialog”, nr 6, s. 156-162.

Kleiner Juliusz (1997), Mickiewicz, t. 2: Dzieje Konrada, cz. 1, Towarzystwo Naukowe KUL, Lublin.

Kopciński Jacek (2016), Powrót „Dziadów”, czyli dwa teatry, w: tegoż, Powrót „Dziadów” i inne szkice teatralne, Uniwersytet Kardynała Stefana Wyszyńskiego, Instytut Książki, Warszawa-Kraków, s. 258-277.

Kosiński Dariusz (2013), Teatra polskie. Rok katastrofy, Instytut Teatralny im. Zbigniewa Raszewskiego, Znak, Warszawa-Kraków.

Marzęcki Radosław (2010), Totalitarny i demokratyczny dyskurs polityczny. Próba uchwycenia ciaggłości, w: Język IV Rzeczypospolitej, red. Maciej Czerwiński, Paweł Nowak, Renata Przybylska, Wydawnictwo umcs, Lublin, s. 135-149.

Mickiewicz Adam (1995), Dziady. Część III, w: tegoż, Dzieła. Wydanie Rocznicowe 1798-1998, t. 3: Dramaty, oprac. Zofia Stefanowska, Czytelnik, Warszawa, s. 117-316.

Niebrzegowska-Bartmińska Stanisława (2010), Aksjologiczne tło demonizacji przeciwnika w kampanii wyborczej 2007 roku, w: Język IV Rzeczypospolitej, red. Maciej Czerwiński, Paweł Nowak, Renata Przybylska, Wydawnictwo umCs, Lublin, s. 347-362.

Niemojewska-Gruszczyńska Zofia (1920), „Dziady” drezdeńskie jako dramat chrześcijański, nakładem Andrzeja Niemojewskiego, Warszawa.

Nowakowski Jan (1989), Wstęp, w: Stanisław Wyspiański, Legion, oprac. Jan Nowakowski, Ossolineum, Wrocław, s. V-LXxxviI.

Pigoń Stanisław (1998), Fundamenty ideowe Legionu oraz Adama Mickiewicza „Skład zasad”, w: tegoż, Zawsze o Nim. Studia i odczyty o Mickiewiczu, wyd. 2 poszerz., Wydawnictwo IBL PAN, Warszawa, s. 469-496, 497-519.

Plata Tomasz (2017), Pośmiertne życie romantyzmu, Akademia Teatralna im. Aleksandra Zalwerowicza, Instytut Teatralny im. Zbigniewa Raszewskiego, Warszawa.

Prussak Maria (1993), „Bohater pochodnia”, w: tejże, „Po ogniu szum wiatru cichego". Wyspiański i mesjanizm, Wydawnictwo IBL PAN, Warszawa, s. 15-66.

Przybylski Ryszard (1993), Stowo i Milczenie Bohatera Polaków. Studium o „Dziadach”, Wydawnictwo IBL PAN, Warszawa.

Rymkiewicz Jarosław Marek (2007), Wieszanie, Sic!, Warszawa. 
Rymkiewicz Jarosław Marek (2010), Posłowie. Czego uczy nas Adam Mickiewicz?, w: tegoż, Wiersze polityczne, Sic!, Warszawa, s. 51-55.

Siwicka Dorota (2013), Nasze widowisko - Dziady, w: „Dziady nasze maja to szczególnie... ". Studia i szkice wspótczesne o dramacie Adama Mickiewicza, red. Ewa Hoffmann-Piotrowska i Andrzej Fabianowski, Wydawnictwo Polonistyki uw, Warszawa, s. 195-204.

Wasilewski Jacek (2010), Dominacja retoryki. Zakorzenienie mitu IV $R P$ w jednej $z$ dwóch antytetycznych narracji o Polsce, w: Język IV Rzeczypospolitej, red. Maciej Czerwiński, Paweł Nowak, Renata Przybylska, Wydawnictwo UMCs, Lublin, s. 103-119.

Weintraub Wiktor (1957), Wyspiański i kompleks Mickiewicza, w: Wyspiański żywy, red. Herminia Naglerowa, B. Świderski, Londyn, s. 188-199.

Weintraub Wiktor (1998), Mickiewicz - mistyczny polityk, w: tegoż, Mickiewicz - mistyczny polityk i inne studia o poecie, wybór i oprac. Zofia Stefanowska, IBL, Warszawa, s. 13-51.

Witkowska Alina (1998), Mickiewicz - stowo i czyn, wyd. 3, PWN, Warszawa.

Wojda Dorota (2012), „Dwie Polski”. Czytanie Rymkiewicza w PRL-u i III $R P$, w: Spór o Rymkiewicza, red. Tomasz Rowiński, Fronda, Warszawa, s. 376-402.

Woźniak-Łabieniec Marzena (2012), O wieszaniu, czyli czynności głęboko humanistycznej, w: Spór o Rymkiewicza, red. Tomasz Rowiński, Fronda, Warszawa, s. 85-103.

Arkadiusz Bagłajewski

\section{Jarosław Jakubowski's Political Romanticism or Rewriting Dziady (on the right wing)}

The article analyses two dramas by Jarosław Jakubowski: Dożynki and Nowy Legion (New legion), which their author designed as attempts at updating the political frame of Mickiewicz's Dziady (Forefathers' Eve), (especially 'Warsaw salon'), read in the context of the 'Smoleńsk romanticism.' The right-wing approach to Mickiewicz's archdrama offers a diagnosis of the social and political divide ('two Poland') in the aspect of the clash between two worldviews: left-wing and liberal versus right-wing. Mickiewicz's authority is supposed to strengthen the right-wing diagnoses, hence it is easy to spot the numerous attempts at instrumental and anachronic reading of the romantic legacy. At the same time, the analysed dramas show the importance and the textual and ideological productivity of the romantic paradigm. 
Keywords: reception of romanticism; romantic paradigm; contemporary drama; right-wing discourse; Jarosław Jakubowski.

Arkadiusz Bagłajewski - profesor doktor habilitowany, pracownik Instytutu Filologii Polskiej UMCS, w latach 2015-2019 dyrektor Instytutu, obecnie kierownik Katedry Historii Literatury Polskiej. Zajmuje się romantyzmem i współczesnością. Jest autorem czterech książek: Ostatni romantyk. Twórczość liryczna Kornela Ujejskiego (1999), „Poezja „trzeciej epoki”. O twórczości Zygmunta Krasińskiego, (2009), Mapy dwudziestolecie 1989-2009. Linie ciagtości (2012), Obecność romantyzmu (2015). Opublikował blisko 300 artykułów, szkiców i recenzji w czołowych czasopismach naukowych i literackich. Był redaktorem kwartalnika literackiego „Kresy” przez cały czas istnienia pisma (1989-2010), zaś w latach 1995-2010 redaktorem naczelnym. Od dwóch kadencji (2015-2019 oraz 2020-2023) jest członkiem Komitetu Nauk o Literaturze PAN. 
